\title{
Sovereign CDS Market: The Role of Dealers in Credit Events
}

Lawrence Jia, Bruno Sultanum, and Elliot Tobin

A credit default swap (CDS) is a credit derivative that can be used as insurance against a reference entity's credit risk, where a reference entity is either a government or corporation that has issued debt. It is formally a bilateral contract between a protection seller and protection buyer. The former is taking a short position in the CDS, while the latter is taking a long position. The protection seller compensates the protection buyer if there is a credit event with respect to any of the bonds issued by the contract's reference entity. Credit events include bankruptcy, failure to pay, and restructuring, among other items. In exchange, the protection buyer makes periodic interest payments to the protection seller until the contract expires.

As a result of their role in the 2008 financial crisis and in the sovereign debt crises in Europe, credit default swaps are among the most controversial derivative instruments. In both corporate and sovereign contexts, proponents of CDS attest to their beneficial effects in providing and transferring liquidity risk during times of distress.

Critics view CDS as speculative bets, especially since CDS holders may hold more CDS than bonds with respect to the reference entity. That is, if a party owns equal amounts of bonds and CDS for a particular reference entity, then the party is completely insured against a negative credit event. In this way, a CDS works pretty much like an insurance policy on a car, house, or any other asset. However, unlike insurance, it is possible to own more CDS protection than the underlying bonds. As a result, CDS contracts make it possible to trade on

- The views expressed in this article are those of the authors and do not necessarily represent those of the Federal Reserve Bank of Richmond or the Federal Reserve System. 
a reference entity's credit risk without having any exposure to the underlying credit, which can be interpreted as a bet on the deterioration of the reference entity's ability to repay its creditors.

In the sovereign CDS market, the reference entity is a country; as a result, increases in default risk could have significant economic impact and ethical considerations. Since CDS markets tend to be more liquid and larger than the corresponding bond market, some academics and members of the media have argued that speculative bets from large traders can artificially drive the price of a CDS contract up. In turn, market participants observe the risk of the underlying bonds to be higher than it actually is, increasing the cost of borrowing for the distressed countries. Thus, this increases the chances of default artificially. In this scenario, buying CDS is functionally equivalent to short selling the bonds. Short selling bonds is nearly impossible due to the lack of liquidity in bond markets; as a result, the presence of a CDS contract allows the sovereign bond's pessimists and optimists to enter the market, increasing price stability of the underlying bond.

Previous literature has examined the role of sovereign credit default swaps and specifically the ban of "naked" CDS in the European Union. In Duffie et al. (1999), research has also been conducted on the endogenous liquidity risk of CDS. However, in the context of distressed countries, the dealer-provided liquidity that this paper introduces is a new area of study. Using our regulatory data from the Depository Trust and Clearing Corporation (DTCC), we are able to see the CDS position of market participants over time.

This paper uses a case study approach to suggest that the critics' conclusion that sovereign CDS markets drive the cost of capital up for countries may be incorrect, or at least the pressure from short positions on CDS does not seem to be coming from large dealers. To better understand the net effects of sovereign CDS markets, we examine the CDS positions of major CDS dealers as risk changes. ${ }^{1}$ Specifically, we use Venezuela, Ukraine, and Argentina as case studies. These three countries have experienced credit events and therefore CDS payouts since 2008.

We observe that the large CDS traders in each market, defined as the top ten traders of each country's CDS, tend to sell (buy) CDS as risk increases (decreases). This is the opposite direction of change one would expect if the large dealers were taking speculative bets. We leave a formal model of this mechanism to a later paper, but the basic logic of how we tie these changes in positions to market liquidity is as follows.

\footnotetext{
${ }^{1}$ We use both CDS spread and bond yield as a measure of risk.
} 
Large and risk-neutral dealers can take CDS positions that may result in a large loss with a nonnegligible probability so long as they perceive the position, combined with the dealer fee, to have a positive expected value. Smaller and risk-averse institutions that may not be able to sustain a large loss, rush to buy protection from the large risk-neutral dealers.

In this way, dealers provide endogenous liquidity in distressed times by market making. This may imply that sovereign CDS trading by CDS dealers can lower endogenous liquidity risk and potentially lower bond spreads during unstable financial periods relative to what they would have been had the sovereign CDS market not existed.

\section{RELATED LITERATURE}

Many analysts and regulators blamed the severe and widespread nature of the 2008 financial crisis on CDS, contending that CDS exacerbated the housing asset bubble They specifically argued that major financial institutions were using CDS for speculation and manipulation with global consequences. These criticisms of CDS were extended during the European sovereign debt crisis beginning in 2009 (Augustin et al., 2014). Sovereign CDS are insurance contracts issued against a country's public bonds. This new wave of criticism on sovereign CDS centered on the sovereign CDS market's role in price discovery and monitoring, spillover liquidity in the underlying sovereign bond markets, and hence, adjustments in borrowing costs for the country in times of distress.

Studies following the Great Recession and European sovereign debt crisis have produced mixed results on the practical uses and risks of CDS markets. We first discuss the structure of sovereign CDS markets and their theoretical role in bond markets. Then, we discuss the capacity of general (corporate and sovereign) CDS in contagion risk, the potential for spillover effects, and price discovery/monitoring. Finally, and most relevant to this paper, we will discuss the potential for sovereign CDS to provide liquidity in their associated sovereign bond markets and what that means for a country's borrowing costs.

As insurance, CDS markets perform two basic functions. First, they allow financial institutions to hedge their credit risk, thereby freeing up regulatory capital to further lend. Second, they let financial institutions take more liquid short positions on bonds (Czech, 2019). The first function is of primary importance to this paper. Theoretically, by purchasing CDS contracts as hedges, financial institutions are potentially able to lend more capital, increasing liquidity in underlying 
bond markets and lowering equilibrium borrowing costs for the bond issuer in question.

However, concerns regarding the practical uses of CDS in the wake of the financial crises have marred their reputation. The first concern of CDS use is its contagion potential and spillover effects into global markets. In Longstaff et al. (2011), the authors observe that global information shocks result in sovereign CDS spreads increasing or decreasing together. If one CDS market responds to new information, this comovement effect can introduce contagion risk to other CDS markets. However, a subsequent study by Caporin et al. (2013) finds that spillover effects of reactions to large CDS spread changes in one CDS market are largely regionally contained, not global in nature. When it comes specifically to spillover liquidity risk, Bai et al. (2012) also did not find a change in the country's fundamentals.

However, having an insurance market can also provide a useful vehicle for price discovery for the underlying entity. For instance, Augustin et al. (2014) found differences in CDS spreads to be useful in predicting options pricing and exchange rates up to one week in advance. A trader has a naked CDS position if it has a larger position in the CDS than the underlying bonds. Duffie (2010) finds that the use of naked CDS trading data is also beneficial to the underlying asset information and therefore increases the efficiency of the bond market. This information efficiency was later supported by Coudert and Gex (2013), who recognized that the derivative market provided better information than the bond market because of higher participation in CDS markets during recessionary periods. In times of distress, bond traders are likely to run from the bond market, while CDS traders stay in the market and provide pricing information.

In addition to price discovery, CDS have also been found to provide valuable information for price monitoring. Ismailescu and Phillips (2011) found CDS to be efficient monitoring tools that increase the overall informational and pricing efficiency in the market of the underlying entity. This can also propagate greater market participation. Portes (2012) also found CDS to be accurate, although not perfect, in pricing credit risk in the long run. However, this same relationship does not hold in the short run.

Most relevant to this paper, the presence of a CDS market on the liquidity of the associated bond market is currently being debated. Historically, a valuable instance in which the use or disuse of CDS impacted liquidity in bond markets is the European Central Bank's (ECB) gradual ban of naked CDS. A market participant owns a naked CDS if she owns more CDS than bonds in a given reference entity. It has been described by Portes (2012) as taking out life insurance on someone 
else's life. While this paper does not differentiate between naked and nonnaked CDS trades, studying bans of general CDS can provide useful literature on CDS's role in capital markets. In the wake of the European sovereign debt crisis, the ECB temporarily banned the trade of naked CDS in 2010. The ECB later permanently banned naked CDS trading in 2011. A study by Sambalaibat (2013) found that the temporary ban increased liquidity in underlying sovereign bond markets, citing a temporary migration of CDS traders to the bond market. However, the same study found that the permanent ban of naked CDS decreased liquidity in the underlying sovereign bond markets.

This paper focuses on countries that have experienced severe defaultrisk episodes. When countries are low on cash, speculation in a CDS market, according to Che and Sethi (2011), can divert much-needed capital away from potential borrowers. The resulting rise in CDS premiums sends information to potential lenders to increase the cost of funding to the government. The government, which is unlikely to afford the higher interest, will become more cash-strapped and only increases long bets in its CDS market: a self-fulfilling prophecy.

But, other literature suggests that the use of CDS can lower the probability of default. Goderis and Wagner (2011) argue that the use of nonnaked CDS can reduce risk for ex-ante default. The authors cite the existence and ownership of insurance policies on sovereign debt as an incentive for the insurance holder to reject any restructuring offer made by the government. Similarly, Salomao (2017) has a similar finding: in distress, the existence of insurance contracts can increase the lender's borrowing power, which incentivizes the borrower to default less often. The author also argues that the existence of insurance contracts can raise debt levels and lower borrowing costs in equilibrium.

The liquidity benefits and risks of CDS have only been studied in the case of the ECB's ban of naked CDS and in theory. We try to contribute to the discussion of CDS as liquidity-providers in underlying bond markets, by analyzing how dealers trade sovereign CDS in both stable and risky time periods, to better understand how the sovereign CDS market can affect liquidity in the underlying sovereign bond market. We find that in times of distress, big CDS dealers act as market-makers by taking shorter (longer) CDS positions as risk increases (decreases). These findings suggest that large dealers provide liquidity to the underlying bond market. 


\section{HISTORICAL BACKGROUND OF SOVEREIGN CREDIT EVENTS}

Prior to describing the trading patterns, we review the historical and economic events that affect the risk of the three countries we use as case studies: Argentina, Ukraine, and Venezuela. All three countries have defaulted on their debt in recent years; however, the reasons and economic conditions differ.

\section{Ukraine}

From 2001 to 2008, Ukraine experienced moderate economic growth that coincided with a global economic boom. A longstanding relationship with the former Soviet Union allowed Ukraine to import oil from Russia at approximately half the price per barrel that Western European suppliers were charging in order to power its mineral and natural resources industries, which comprise most of Ukraine's economic output. This dependency on foreign oil amounted to approximately 70 percent of its total oil usage by the mid-2000s. During this time, the Ukrainian economy averaged 7.4 percent annualized growth and large capital inflows from foreign investors.

However, Ukrainian economic woes began in 2006 when cheap access to Russian oil began to diminish, limiting domestic production and exports. This period of supply instability was exacerbated by the 2008 financial crisis, in which the International Monetary Fund (IMF) gave two stand-by disbursements that greatly helped Ukraine weather the crisis. However, increasingly unstable debt loads reached 91.5 percent of the Ukrainian GDP in 2009, and that proved critical in the coming default.

In 2013, new Russian trade restrictions and an inability to increase industrial production led to foreign investors rating default probabilities at approximately 50 percent in the swap market. Moody's Investor Service in 2013 also gave Ukraine's credit a rating of Caa1, which limited foreign investment and economic growth. Ensuing political instability, with the ousting of sitting President Viktor Yanukovych in 2014 and the annexation of Crimea by Russia, coincided with a 6.8 percent and 10.4 percent decline in GDP in 2014 and 2015, respectively. Ukraine also experienced a currency crisis in February 2014 when the government began using the hryvnia as a floating currency, which caused a 70 percent depreciation against the U.S. dollar.

In December 2015, Ukraine missed interest payments on a $\$ 3$ billion loan to Russia, which the International Swaps and Derivatives Association (ISDA) determined was a credit event. The IMF then offered a $\$ 17.5$ billion, four-year loan program in 2016 that helped stabilize 
the hemorrhaging economy. With a positive global economic output, a small recovery in oil prices, stronger worker productivity, and a government corruption reform program, Ukraine has experienced positive economic growth since 2016.

\section{Venezuela}

Despite having the largest proven oil reserves in the world and being the sixth largest member of the Organization of Petroleum Exporting Countries (OPEC), the Venezuelan economy has undergone significant stresses in the past two decades. Petroleum accounts for approximately 95 percent of Venezuela's total exports, and its economic growth largely depends on oil prices.

The Venezuelan economy experienced significant inflation in the late 1990s, peaking near 100 percent in 1996. Inflation after the election of Hugo Chavez calmed to approximately 35 percent from 19962001. Further political and social unrest after the ascension of Chavez in 1998 have only exacerbated Venezuela's economic crisis. For instance, the 2002 attempted coup and the 2002-03 labor strike returned economic growth to pre-Chavez levels. The economic decline continued into the late 2000s, with a chronic housing shortage, further unsustainable inflation, political unrest, and high poverty rate. In 2009, the IMF categorized the Venezuelan recovery as "weak and delayed," especially in relation to the relative economic growth of other South American countries and its largest trading partner, the United States.

Tremors of Venezuelan economic stress occurred in early 2014 with a global depression in crude oil prices. Although Venezuela has the world's largest proven oil reserves, its economy's heavy reliance on petroleum exports makes its economic growth and prosperity largely de-

pendent on oil prices. Preceding the mid-2014 oil glut, 96 percent of Venezuela's fiscal revenue originated from oil production. An international oil glut formed after a production boost in the North American shale oil industry, lesser demand from China, and a lack of OPEC policy uniformity. At its peak, the global economy was outputting over two million barrels of oil per day. The price per barrel of Venezuelan oil fell from over $\$ 100$ in 2012 to approximately $\$ 30$ in 2015 . As a result, Venezuela ended almost half a decade of steady economic growth with a 5 percent decline in GDP in the first quarter of 2014. The National Assembly of Venezuela reported inflation to be approximately 4,000 percent in 2017. On December 30, 2017, ISDA declared a credit event after the Venezuelan government missed two interest payments amounting to a combined $\$ 200$ million. Since the selective default, Venezuela has defaulted on eighteen other sovereign bonds. 


\section{Argentina}

Within thirteen years, Argentina has experienced two different types of default. First, Argentina defaulted in 2001 on $\$ 83$ billion of debt. Second, Argentina defaulted in 2014 on $\$ 132$ billion of debt after a U.S. Supreme Court ruling in Republic of Argentina v. NML Capital Ltd. said that Argentina must repay investors in full from their 2001 default.

The Argentinian economy has struggled with stagflation, hyperinflation, capital flight, and corruption beginning with a military dictatorship that started in 1976. After a brief period of rapid economic growth under a democratic government and Minister of Economy Domingo Cavallo's anti-inflation campaign, Argentina experienced another recession beginning in 1998. Regional economic crises in Brazil and commodities pricing shocks contributed to slow growth, high unemployment, and deflation. The 2001 Argentinian default was framed by massive political riots in December 2001 and a struggling export economy. Consequently, the Argentinian government defaulted on $\$ 83$ billion in debt after which 93 percent of investors agreed to the restructuring terms, which involved a 70 percent haircut on repayment.

Although the 2014 default was preceded by relative economic growth between 2002 and 2013, the export-dominated Argentinian economy struggled again with a sluggish world economy. Further, a unilateral devaluation of currency, as evidenced with a 1,300 percent increase in M3 money supply since 2002, has also contributed to the world's third highest inflation rate in 2014 at an official rate of approximately 10 percent. However, news sources speculate the actual inflation rate more realistically hovers at 25 percent.

In this context, the remaining 7 percent of investors who did not accept the restructuring agreement in 2001 demanded to be repaid in full. Following the 2001 default, the Argentinian government declared all debt repayments to be pari passu, that is, repaid with no preference to investors. The remaining 7 percent of investors then sued in the U.S. Supreme Court, which upheld lower court rulings in Republic of Argentina v. NML Capital Ltd. that Argentina's foreign assets were not immune from discovery, which resulted in the obligation to pay all debts in full, valued at approximately $\$ 132$ billion. As a result, the Argentinian government declared it would "imminently be in default" on July 30, 2014, after missing a $\$ 529$ million interest payment. Standard and Poor's then declared Argentina to be in selective default in the autumn of 2014 . 


\section{DATA}

We obtained the dealer CDS positions using the DTCC. The DoddFrank Wall Street Reform and Consumer Protection Act requires realtime reporting of all swap contracts to a registered swap data repository (SDR). The DTCC operates a registered SDR on CDS. The DoddFrank Act also requires SDRs to make all reported data available to appropriate prudential regulators. (See Sections 727 and 728 of the Dodd-Frank Act.) As a prudential regulator, members of the Federal Reserve System have access to the transactions and positions involving individual parties, counterparties, or reference entities that are regulated by the Federal Reserve. Using the DTCC data, we recover a time series of the average CDS positions of the top ten dealers in three different countries from 2013 through 2017.

To get a measure of risk, we use both bond yields and CDS spreads. To obtain bond prices, a list of deliverable obligations from the CDS auction was obtained from the Credit Derivatives Determinations Committee for each country. These bonds were listed with a maturity date, coupon value, and CUSIP/ISIN number. Bloomberg was used to obtain historical bond prices from January 4, 2010, to February 22, 2019. Specifically, two sets of bond price measurements were obtained. First, the yield to maturity time series was gathered. Second, a yield to benchmark measurement was gathered, which values a bond against an internal Bloomberg benchmark. We chose to construct our own price index because the price of the deliverable bonds is the most relevant. Some outstanding sovereign bonds are included in available price indices by JPMorgan and Bloomberg, but are not deliverable in auction. Nonetheless, using these indices does not change this paper's results. Additionally, the initial issue amount was recorded for each bond.

We also collected CDS spreads from Bloomberg for each of the three countries. The correlation between CDS spreads and yields is near 1 . Since Ukraine does not have bond data for most of the sample, we use the CDS spread data. Nonetheless, the results are robust to usage of either yield measures in the countries in which the yield data exists.

To create the bond indices for each country, a weighted average of the deliverable bond prices for each country was used. ${ }^{2}$ Each date has varying numbers of bonds outstanding as the country retires and issues debt over time. As a result, the individual bond issue amount as a fraction of the total issue amount for the number of bonds available for a certain date was used to weight and standardize the bond prices. This

\footnotetext{
${ }^{2}$ Deliverable bonds are the bonds deliverable at the CDS auction for each country. That is, these are the bonds for which the CDS offers protection.
} 
was multiplied by the bond price, in yield-to-maturity and yield-tobenchmark, to obtain a price index of the overall deliverable obligation bond market in Argentina, Ukraine, and Venezuela. Note that a price index was not needed for CDS spreads since a CDS offers protection for all deliverable bonds.

\section{FINDINGS}

In this section, we highlight how each of the three countries' financial crises illustrate how dealers provide liquidity during financial crises by selling protection. In general, we found that dealers take the opposite position of the market in times of distress, functioning as marketmakers. Specifically, as risk increased in a country's underlying bond market, dealers decreased their CDS positions. We define big dealers as the ten largest volume traders of the specific CDS over our sample period. Our results are robust to using the five biggest dealers (another common measure). We use the CDS spread as our measure of risk, where an increasing CDS spread indicates greater risk. Our results are the same if we use bond yield. Furthermore, we often refer to long and short positions. If the big dealers have a short (long) position, they are net sellers (buyers) of CDS. We time detrended the position and CDS data. Without detrending, our results may have been skewed because the CDS market has been shrinking over the time periods considered due to changes in the regulatory landscape. However, the general findings from this section are robust to using the raw data without detrending it.

\section{Ukraine}

In Ukraine, the dealer positions and CDS spread show a very clear inverse relationship. From the beginning of the sample period to March 2015, risk increased as the dealer position decreased. From March 2015 to the end of the sample period, risk decreased and the dealer position rose. The latter scenario will not be seen as commonly later in the paper.

First, from January 2013 to March 2015, the CDS spread increased by 4500 basis points as Ukraine faced hyperinflation and conflict with Russia. During the same period, the net CDS position of big CDS dealers decreased from a $\$ 75$ million long position to a $\$ 150$ million short position.

Second, following the disbursement deal with the IMF, reduced tensions with Russia, and an increasingly positive economic outlook in 2015, the period from March 2015 to March 2018 shows a 4,000 basis 
Figure 1 Ukraine: Big Dealer Position vs. CDS Spread

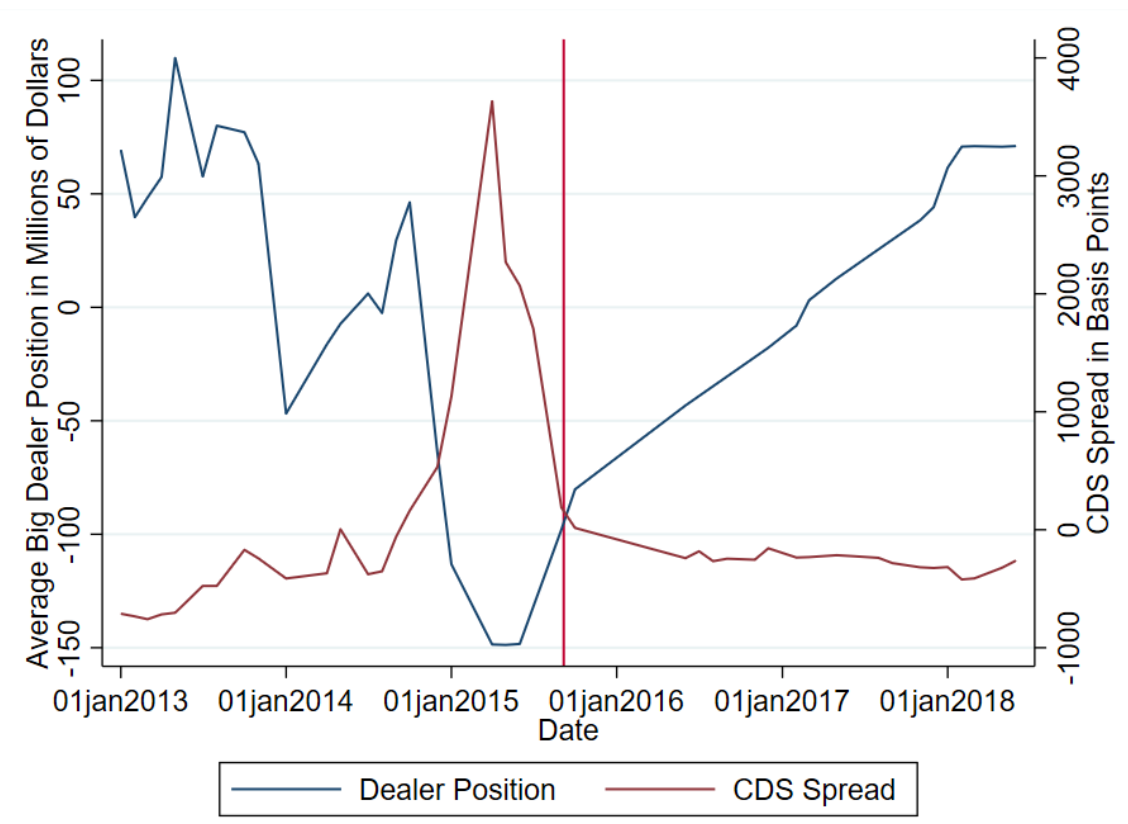

Notes: Both dealer position and CDS spread are time-detrended. The Ukraine CDS auction date of October 6, 2015, is plotted as a red vertical line to give an idea of the default date. Big dealers are defined as the ten highest-volume traders. Dealer position is considered positive if the dealers, on net, own protection and is considered negative if they, on net, sell protection.

point decrease in CDS spreads, a dramatic reduction in the country's risk. During the same period, the net CDS position of big CDS dealers increased by $\$ 230$ million.

The correlation between the CDS spread and the dealer position is -0.783 . The strong negative correlation is expected based on the strong inverse relationship over the entire sample period.

\section{Venezuela}

In Venezuela, the time period from the beginning of 2017 to mid-2018 strongly supports our hypothesis that big dealers reduce their position in CDS as risk increases. This time period includes Venezuela's first selective default in late November 2017. This selective default also 
Figure 2 Venezuela: Big Dealer Position vs. CDS Spread

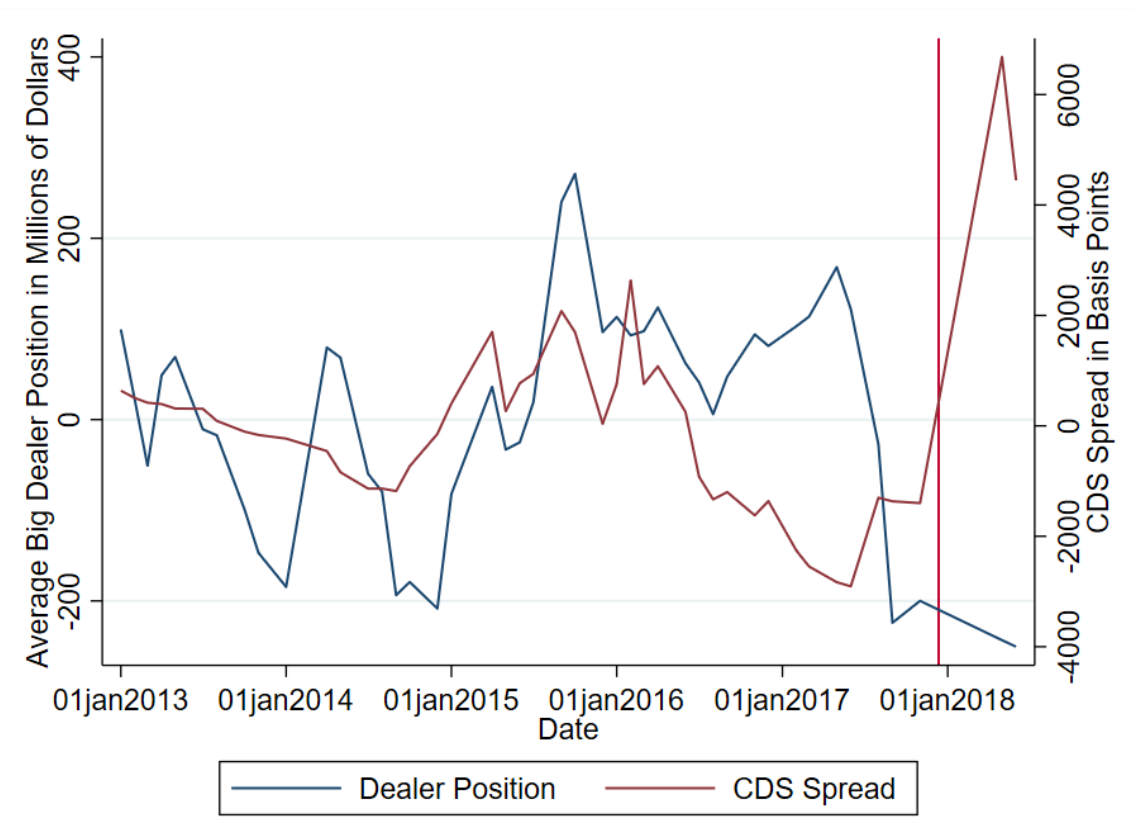

Notes: Both dealer position and CDS spread are time-detrended. Big dealers are defined as the ten highest-volume traders. The Venezuela CDS auction date of December 13, 2017, is plotted as a red vertical line to give an idea of the default date. Dealer position is considered positive if the dealers, on net, own protection and is considered negative if they, on net, sell protection.

caused global worries that debt repayments by the Venezuelan government would not hold. ISDA determined that a credit event took place after a missed interest payment. As a result, ratings agencies declared Venezuela to be in selective default. Venezuelan President Nicolás Maduro declared that all sovereign debts must be "refinanced or restructured." The initial increase in bond spread beginning in June of 2017 reflected a global worry that Venezuela would be imminently defaulting on its debt payments. Investors and media outlets almost unanimously anticipated this selective default would be the first of more than twenty defaults tha have occurred since 2017. Beginning in June 2017, the indexed Venezuelan bond spread increased almost 100 basis points. 
The right side (post January 1, 2017) of Figure 2 depicts the dealer position and CDS spread over the time period in question. Once news of the selective default and its subsequent risks was evident, the CDS spread increased significantly to over 6,000 basis points. As the CDS spread gradually increased in mid-2017 but prior to the sharp increase in spread, the dealers sold $\$ 400$ million of CDS in just a few months, switching from a net long to a net short position. This is the opposite response expected from speculators. The Venezuela example not only demonstrates how dealers sell CDS as risk increases, but also that the action can occur prior to significantly rising spreads. One possible scenario to explain this is the following. Small risk-averse firms became concerned about the possibility of a Venezuelan default a few months prior to the default becoming extremely imminent and rushed to buy protection from the dealers. Regardless of the exact reasons, the shorting of CDS as risk increases is suggestive that dealers are providing liquidity to the market and not speculating.

While the post-2017 period is most indicative of dealers selling (buying) CDS as risk increases (decreases), the correlation between CDS and dealer position is -0.153 across the whole sample period. However, prior to 2017, there is only a slightly negative correlation. Nonetheless, this suggests that dealers taking the opposite position of speculative bettors is also true during more moderate periods of increased risk.

\section{Argentina}

For Argentina, we focus on the CDS spreads and position after July 2016, following the U.S. Supreme Court ruling in Republic of Argentina v. NML Holdings Ltd.. From 2013 to mid-2016, the Argentinian swap market was frozen from trading as the case was pending litigation. The court ruled that Argentina had the obligation to pay back all debts in full related to their earlier default, valued at approximately $\$ 132$ billion.

In the period from June 2016 to December 2017, (see Figure 3) the CDS spread decreased by approximately 50 basis points. During the same period, the big CDS dealers' average position increased from a net short position of approximately $\$ 275$ million to a net long position of approximately $\$ 300$ million. That is, the dealers bought CDS as risk decreased.

The converse relationship is also demonstrated from January 2018 to June 2018 (see Figure 3), when the CDS spread increased by approximately 150 basis points. During the same period, the big CDS dealers' average position decreased by $\$ 875$ million from a net long position of 
Figure 3 Argentina: Big Dealer Position vs. CDS Spread

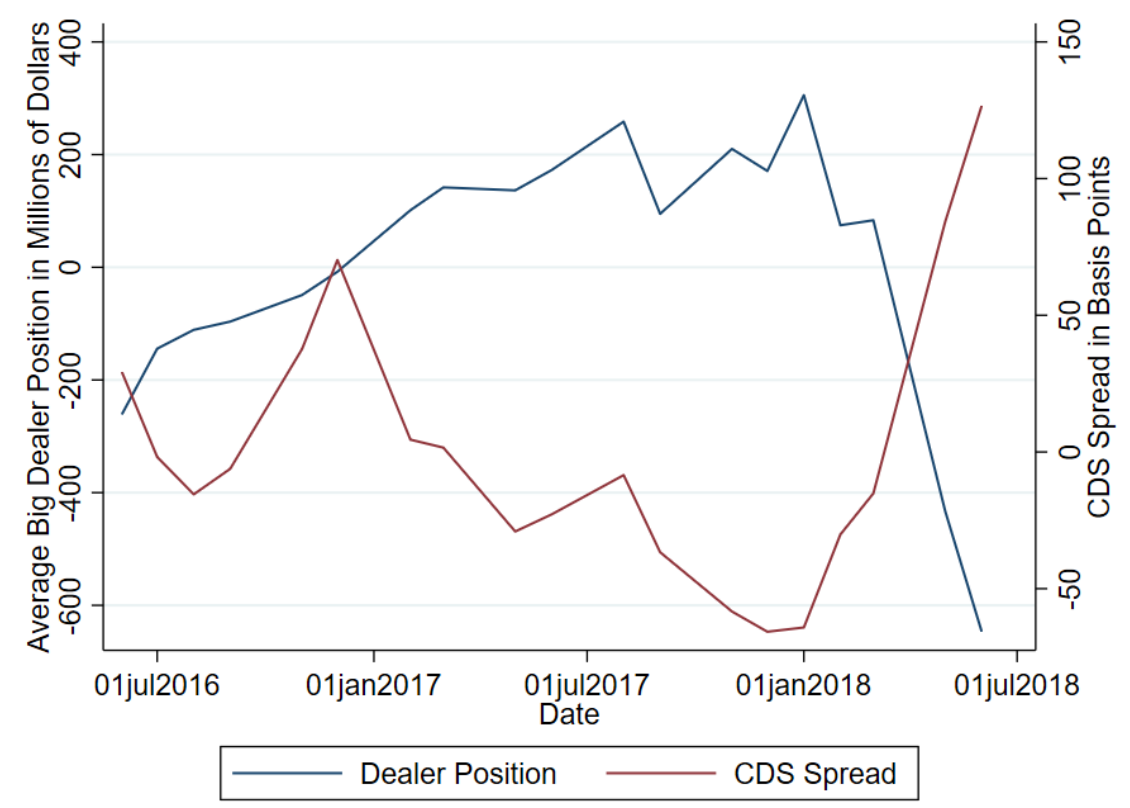

Notes: Both dealer position and CDS spread are time-detrended. Big dealers are defined as the ten highest-volume traders. Dealer position is considered positive if the dealers, on net, own protection and considered negative if they, on net, sell protection. Due to a long time period of no trading because of the pending U.S. court decision, we start our analysis in June 2016, so the default is not in this time period.

approximately $\$ 275$ million to a net short position of more than $\$ 600$ million.

The correlation between the CDS spread and the average big dealer position yielded a value of -0.697 , which shows a strong, negative correlation. This indicates that what we have found in the two episodes discussed previously is also true in the Argentinian sample. That is, as risk increases (decreases), dealers sell (buy) CDS.

\section{EXTENDING OUR FINDINGS}

Figure 4, which is extracted from Chaumont et al. (2020), displays the relationship between average yield and average dealer position aggregated by country from 2013-18. There is a downward trend in Figure 


\section{Figure 4 Cross-Country Analysis}

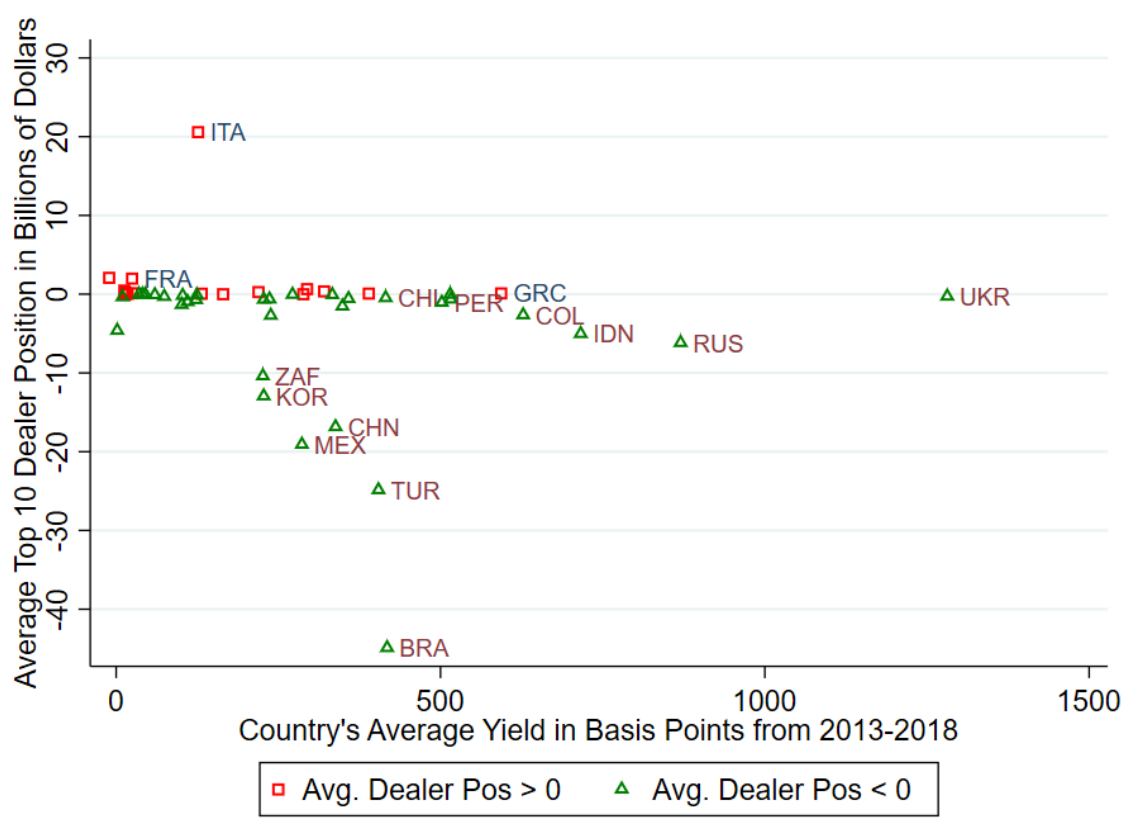

4 , with a correlation coefficient of -0.2 . That is, the average dealer CDS position decreases as a country's average risk increases. This mirrors our conclusions from the three case studies above, where we find that the dealer CDS position decreases as risk increases within each country. To the extent that the cross-country relationship is indicative of the intracountry relationship, this is evidence that our conclusion from these case studies generally applies to other countries. Nonetheless, one could be concerned that within each country represented in Figure 4, dealer positions do not decrease as risk increases. Perhaps the inverse relationship only holds when a country is significantly distressed.

Chaumont et al. (2020) address these concerns by using more rigorous empirical specifications to determine the relationship between risk and dealer position. By controlling for country, dealer, and time-fixed effects, they determine the relationship between risk and dealer position within each country. Nondistressed and distressed countries are also included in the sample; as a result, they are able to determine if the effect found in this paper is only true in distressed countries. In several specifications and robustness checks, they find that as risk increases (decreases), dealer CDS positions decrease (increase) within 
each country regardless of risk. This is the same conclusion found in the case studies above.

Chaumont et al. (2020) also propose a formal model aimed at tying the changes in CDS position to bond market stability and liquidity, which is assumed in this paper. Combined with the empirical results in this paper, their model would suggest that the existence of sovereign CDS markets is beneficial to borrowers and lowers the cost of borrowing for countries.

REFERENCES

Augustin, Patrick, Marti G. Subrahmanyam, Dragon Yongjun Tang, Sarah Qian Wang. 2014. "Credit Default Swaps: A Survey." Foundations and Trends in Finance 9 (December): (1-196).

Bai, Jennie, Christian Julliard, and Kathy Yuan. 2012. "Eurozone Sovereign Bond Crisis: Liquidity or Fundamental Contagion," Manuscript.

Caporin, Massimiliano, Loriana Pelizzon, Francesco Ravazzolo, and Roberto Rigobon. 2015. "Measuring Sovereign Contagion in Europe." Journal of Financial Stability 34 (February): 150-81.

Chaumont, Gaston, Grey Gordon, Bruno Sultanum, and Elliot Tobin. 2020. "Sovereign Default and Credit Default Swaps: The Role of Dealers' Liquidity Provision." Manuscript (Federal Reserve Bank of Richmond).

Che, Yeon-Koo. 2010. "Credit Derivatives and the Cost of Capital." SSRN Electronic Journal, August.

Coudert, Virginie, and Mathieu Gex. 2010. "The Credit Default Swap Market and the Settlement of Large Defaults." International Economics 3 (March): 91-120.

Czech, Roberto. 2019. "Credit Default Swaps and Corporate Bond Trading." Bank of England Staff Working Paper No. 810, July.

Duffie, Darrell, and Kenneth Singleton. 1999. "Modeling Term Structure of Defaultable Bonds." Review of Financial Studies 12 (February): 687-720.

Duffie, Darrell. 2010. "Is There a Case for Banning Short Speculation in Sovereign Bond Markets?" Bank of France Financial Stability Review, June. 
Goderis, Benedikt, and Wolf Wagner. 2009. "Credit Derivatives and Sovereign Debt Crises," Munich Personal RePEc Archive Paper No. 17314, March.

Ismailescu, Iuliana, and Blake Phillips. 2012. "Savior or Sinner? Credit Default Swaps and the Market for Sovereign Debt," SSRN Electonic Journal, January.

Portes, Richard. 2010. "Ban Naked CDS," Eurointelligence, March.

Salomao, Juliana. 2017. "Sovereign Debt Renegotiation and Credit Default Swaps," Journal of Monetary Economics 90 (October): $50-63$.

Sambalaibat, Batchimeg. 2012. "Credit Default Swaps as Sovereign Debt Collateral," Manuscript, June. 